\title{
The Effect of Scientific Inquiry Learning Model for Student's Science Process Skill and Self Efficacy in The Static Fluid Subject
}

\author{
Maria Ulfah \\ Postgraduate studies, State \\ University of Medan \\ Medan, Indonesia \\ Email; ulfah240912@gmail.com
}

\author{
Mara Bangun Harahap \\ Lecturer, State University of Medan, \\ Indonesia
}

\author{
Juniastel Rajagukguk \\ Lecturer, State University of Medan, \\ Indonesia
}

\begin{abstract}
This study aimed to know the effects of Scientific inquiry learning model to students' Science Process skill and Self Efficacy in the static fluid subject. This study used a quasi experiment with two group pretest posttest design. The population of this study was all the students grade XI in Senior High School Al - Azhar Medan, North Sumatera academic 2017/2018. The sample selection by cluster random sampling namely XI Science- $C$ grade as experiment class implemented scientific inquiry learning model and XI Science-B grade as control class implemented conventional learning. The instruments of the research were valid essay test of science process skill and questionnaire of self - efficacy. From result of study was students' science process skill taught by Scientific Inquiry Learning better than conventional learning. Students'Science Process skill have self - efficacy high better than students' conventional learning.
\end{abstract}

Keywords - Scientific Inquiry Learning Model; Science Process skill; self - efficacy,

\section{INTRODUCTION}

The process of building physics in students can begin with do some activity that is observing, asking questions, making a hypothesis, predict, find patterns and relationships, communicate, to design and create, plan and conduct investigations as well as measuring and counting. These activities are part of the science process skills (KPS). KPS serves as competence for effective learning in science and technology, problem solving, individual and social development (Omema, 2016). KPS stressed on formation of skills to acquire knowledge and communicating then to familiarize students become a physicist can be expressed that students need to be equipped KPS.

Based on the results of the interviews of researchers with some random students in High School School of Al-Azhar, note that they rarely do practical work in the laboratory, but in the schools there is the laboratory. This be against KPS students who did not develop because rarely do practical work, and less trained do KPS. This was confirmed when students do practical work, students look confused in following the steps in the student worksheet given teacher. Students are less able to observe phenomena that occur when practical, less able to communicate with a group of friends, less serious, was not able to make a correct conclusion and tend to ask any teacher will do the experiment. In the meantime if the students used to doing practical work, thus KPS students could increase as students become accustomed to observe, ask questions, create a hypothesis, predict, find patterns and relationships, communicate, to design and create, plan and investigations as well as measuring and counting. Such activity is an indicator of the KPS students.

KPS students who did not develop terhadapa also has the students confidence. This statement is supported by Ceylan (2016) self-efficacy related to KPS students, self-efficacy of students who initially low began to increase because in the formation of heterogeneous groups with self-efficacy of students that high. Self-efficacy according to Bandura (Kathleen: 2016) is the consideration of a person about himself to achieve levels of performance (performasi) to the desired or specified as well as affect the action. Responding to the above problem is need for model involving active learning students to enhance student learning outcomes and KPS, that one is a learning model of scientific inquiry. Based on the above description, the author interested in research with the title: " The Influence Of Model Learning Scientific Inquiry Science Process Skills and Against SelfEfficacy Students on the material Fluid Static ".

\section{METHOD}

This research was a quasi experimental research with two group pretest-posttest design. The population of this research was second semester of class XI academic year 2017/2018 at Senior High School Al - Azhar Medan,North Sumatera,Indonesia. The sample of this research were two 
classes that consisted of 125 student's by using class random sampling technique. Class XI Science-C was experimental class taught by scientific inquiry model, class XI Science-B was control class taught by conventional learning. Variables of this research consisted of independent and dependent variable. The independent variable was scientific inquiry learning model, and the dependent variable was science process skill and self - efficacy. The treatment instruments were lesson plan, handout, and student workbook. Measurement instruments consisted of valid essay test of science process skill and questionnaire of self self - efficacy that fulfilled validity and reliability requirements. The material was essay test of fluid static for second semester of class XI. The data were analyzed by using prerequisite and hypothesis test. The normality test were analyzed by Kolmogorov-Smirnov Test. The homogeneity test were analyzed by Levene's Test of equality error variance. Hypothesis test were analyzed by using independent sample t-test with the level of significance 0.05 .

\section{RESULT}

Student's science process skill on the control class and experiment class shown in Table 1.

TABLE 1. Pretest and Posttest data of students ' science process skill

\begin{tabular}{|l|l|l|}
\hline Class & \multicolumn{2}{|c|}{$\begin{array}{c}\text { Average Student } \\
\text { science process } \\
\text { skill }\end{array}$} \\
\hline & Pretest & Postest \\
\hline Experiment & 33.92 & 75.52 \\
\hline Control & 30.56 & 57.28 \\
\hline
\end{tabular}

Based on Table 1, a description of the mean values of science process skill of pretest and posttest students in the control class and experiment class is the U.S. follows: pretest in control class 30.56 and experiment class 33.92 . Posttest control class 57.28 and experiment class 75.52 .

Student's self-efficacy on the control class and experiment class shown in Table 1.

TABLE 2 . Pretest and Posttest data of students ' science process skill

\begin{tabular}{|l|l|l|}
\hline Class & \multicolumn{2}{|c|}{$\begin{array}{c}\text { Average Student } \\
\text { self-efficacy }\end{array}$} \\
\hline & Pretest & Postest \\
\hline Experiment & 55.28 & 78.64 \\
\hline Control & 56.88 & 66.28 \\
\hline
\end{tabular}

Based on Table 2, a description of the mean values of self-efficacy of pretest and posttest students in the control class and experiment class is the U.S. follows: pretest in control class 56.88 and experiment class 55.28. Posttest control class 66.28 and experiment class 78.64 .
TABLE 3. Hypothesis Test Data Science Process Skills Postes Class experimentation and Control Classes

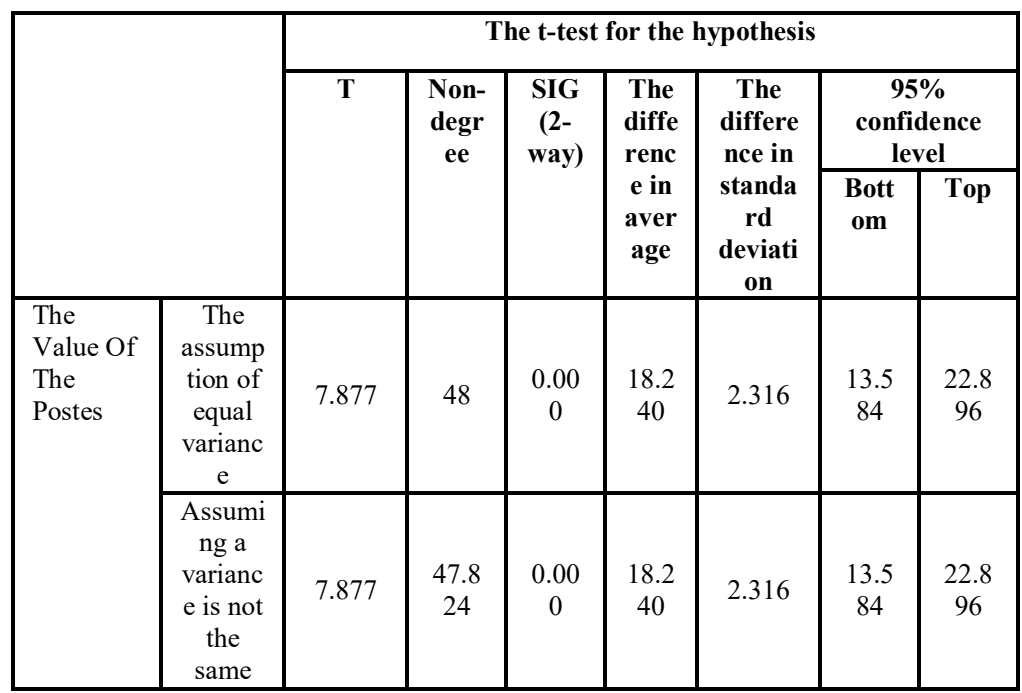

Based on Table 3, significant value (sig 2-way) is 0.000 , on the conditions to see the influence that is used t test (sig 1direction) is significant obtained was significant from $1 / 22$ way i.e. 0.000 , because the value of smaller significance

from 0.05 then Science process skills or accepted students class experiments better than science process skills grade control.

TABLE 4. Hypothesis Test Data Postes Self-Efficac Experiment Class and Grade Control

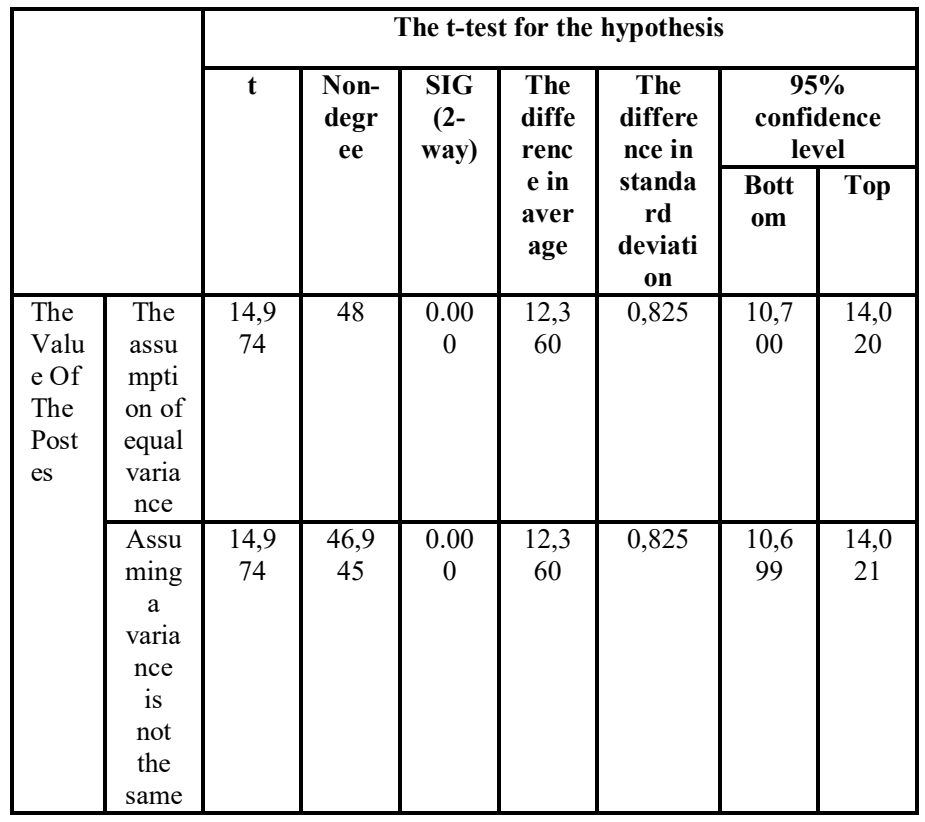

Based on Table 4, significant value (sig 2-way) is 0.000 , on the conditions to see the influence that is used $t$ test (sig 1-direction) is significant obtained was significant 
from $1 / 2$ 2-way i.e. 0.000 , because the value of smaller significance from 0.05 then received or self-efficacy of students class experiments better than the self-efficacy of students of the class of the control.

\section{DISCUSSION}

\section{A. The Influence Of The Learning Models Of Scientific Inquiry To Science Process Skills Of Students}

Based on the research that has been done, the learning model applied in the classroom experiment is scientific inquiry. Models of scientific inquiry is never applied in the process of learning physics in high school so that make AlAzhar students confusion against the learning model of scientific inquiry. Therefore, the researcher first describes the learning model of scientific inquiry to the students before the study began. Of each meeting has done there is the influence of model scientific inquiry against an increase in the activity of the science process skills. Improved that greatly influences the process of science skills students can be seen on phase the third of scientific inquiry that is identified in the investigation phase. In this phase, students are more actively find ways - ways to overcome the problem, design an experiment again, manipulate data properly and developed the idea of the experiment. It can also be seen in Table 4.9 shows the value of the science process skills postest students increased from an average of pretest 33.92 to an average of 75.52 posttest. Results from such postest shows insufficient values because there are still some students who are not actively doing practical work, and do not like learning physics.

\section{B. The Influence Of Model Learning Scientific Inquiry To The Self-Efficacy Of Students}

Based on the research that has been done, the learning model applied in the classroom experiment is scientific inquiry. Models of scientific inquiry is never applied in the process of learning physics in high school so that make AlAzhar students confusion against the learning model of scientific inquiry. Therefore, the researcher first describes the learning model of scientific inquiry to the students before the study began.

Of each meeting has done there is the influence model scientific inquiry against increased self-efficacy students . Improved that greatly influences the process of science skills students can be seen on phase the fourth of scientific inquiry i.e. phase draw conclusions. In this phase, students are more actively conveyed the conclusions of the experiment results against other groups. Students are also more confident in defending his argument and more actively argued with another group. It can also be seen in Table 4.13 shows the value of the postes self-efficacy of students increased from an average of pretes 55.28 to an average of 78.64 postes. Results from such postes shows insufficient values because there are still some students who are not actively doing practical work, and do not like learning physics.

The influence of model learning scientific inquiry will enhance self-efficacy of the students because the students trained investigations are applied on the model of scientific inquiry in the phase of the lesson. On this research obtained corroborating evidence that self-efficacy of students who get the treatment model of learning scientific inquiry was more better than students who get treatment learning conventional. Models of scientific inquiry give significant effects against the self-efficacy of students. The research is in line with research Ceylan (2016:610) explained that an increase in self-efficacy of students taught using instructional models of scientific inquiry.

The similarity of this research with previous research that is in terms of free variables that use the model of learning scientific inquiry and bound variables are used i.e. self-efficacy of students. The results showed that the average postes self-efficacy in experimental classes are better than in the control class. The difference with previous research i.e. research materials in biology. The learning model can be influential in theoretical and empirical, while theory indicates that existing models can increase the selected variable means the influential theoretical model counts time researchers have implementing a model of learning and has been tested using statistical tests and in accordance with the hypothesis that there is a meaning to the model has succeeded in the empirical. Weakness in the study is less consider and ignore the comprehension of the students so that students who are basically active in class learning outcomes has increased. As for students who are not active, just sit on the knowledge presented the teacher. Therefore an increase in the results of the study of physics students who obtained student was not significant when viewed from its average value. The next Researcher can consider and ignore the comprehension of the students so that all the students actively in the learning process.

\section{CONCLUSION}

Based on the results of analysis and discussion, it was obtained some conclusions as the following:

1. The Learning Model of scientific inquiry is designed to involve students in research issues that really orisisnil with the way they turned on investigation, helped them identify a conceptual problem or methodological in the field and invite them to devise ways of solving problems. Learning scientific inquiry gives the opportunity to the students to develop a deeper understanding of science concepts and forms of scientific knowledge of students.

2. Science process Skills of students using a learning model of scientific inquiry is better than students who use conventional learning. Science process skills of students in the classroom experiment above an average of 75.52 science process skills and grade control below an average of 57.28. The results showed that the 
hypothesis of significant value $0.00<\alpha=0.05$ so that the hypothesis $\mathrm{H}_{\mathrm{a}}$ welcome. There is the influence of model learning scientific inquiry science process skills against students.

3. Self-efficacy students who use the learning model of scientific inquiry is better than students who use conventional learning. Self-efficacy students in the class of experiments over an average of 78.64 and selfefficacy of students under the control of the class average of 66.28. The results showed that the hypothesis of significant value $0.00<\alpha=0.05$ so that the hypothesis $\mathrm{H}_{\mathrm{a}}$ welcome. There is the influence of model learning scientific inquiry against the selfefficacy of students.

\section{References}

[1] Arends, r. 2008. Learning To Teach. Student Library Publisher: Yogyakarta.

[2] Arikunto, s. 2006 . The Basics Of Evaluation Of Education Revised Edition. Jakarta: The Earth Revised.

[3] Arsanti, T.A. 2009. The relationship between goal setting, Self Efficacy and performance. Journal of Business and Economics (JBE) .2 (16): 97-110.

[4] Arslan, Nihan. 2017. Investigating the Relationship between Educational Stress and Emotional Self-Efficacy. Universal Journal of Educational Research, 5 (10), 1736-1740.

[5] Aunurahman. 2011. the learning and Learning. Bandung: Alfabeta

[6] Baharuddin and Wahyuni. 2007. a theory of Learning and learning. Jakarta: Ar Ruzz Media

[7] BANDURA, a. 1997. Self-efficacy. In V.S. Ramachaudran (Ed.). Encyclopedia of human behavior (4): 1-14.

[8] Buyruk, Arslan a. \& Ogan Bekiroglu, f. 2018. Comparison of PreService Physics teacher's Conceptual Understanding of Dynamics in a Model-Based Scientific Inquiry and Scientific Inquiry Environments. Journal of Educatioal Science, Environment and Health. 4 (1), 93-109.

[9] Chih-Hsuan Wang, Jamie Harrison, Victoria Cardullo, \& Lin Xi. 2018. Exploring the Relationship Among International Students English Self-
Efficacy, Using English to Learn Self-Efficacy, and Academic SelfEfficacy. Journal of International Students, 8 (1), 233-250.

[10]Dahar, R. W. . 2011. the theories of learning and learning. Jakarta: Eason

[11]Dimyati and Mudjiono. 2002. Learning and learning. Jakarta: Cipta Rineka.

[12]Djamarah, z. 2000. Teaching And Learning Strategies. Jakarta: Cipta Rineka.

[13] Dogan, Nihal. 2017. Blending Problem Based Learning and History of Science Approaches to Enhance Views about Scientific Inquiry: New Wine in an Old Bottle. Journal of Education and Training Studies, 5 (10), 99-112.

[14]Duruka, Umit, Abuzer Akgüna, Ceylan Doğanb, Fatma Gülsuyuc. 2017. Examining the Learning Outcomes Included in The Turkish Science Curriculum in Terms of the Science Process Skills: A Document Analysis with Standars-Based Assessment. International Journal of Educational, Enviromental \& Sciences 12 (2), 117-142.

[15] Ertikanto, Chandra, Herpratiwi, Tina Yunarti \& Andrian S. 2017. Development and Evaluation of a Model-Supported Scientific Inquiry Training Program for Elementary Teachers in Indonesia. International Journal of Instruction, 10 (3), 93-108.

[16] Farrand, Kathleen, Tiffany \& Margilee. 2016. the Self-Efficacy of Students with Visual Impairments Before and After Participation in an Inquiry-Based Camp . Journal of Science Education, 9 (1), 50-60.

[17]Fauzi, M.A., \& Firmansyah. 2011. the contribution of Metacognition in Mathematical Self Efficacy in developing students inside. 1 (12), 3552.

[18] Fraser, William j. 2017. Science Teacher Educators 'Engagement with Pedagogical Content Knowledge and Scientific Inquiry in Predominantly Paper-Based Distance Learning Programs. Journal of Distance Education, 18 (4), 35-51.

[19] Gelişli, Yücel, \& Lyazzat Beisenbayeva. 2017. Scientific Inquiry Competency Perception Scale (The case of Massimov Post-Graduate Students) Reliability and Validity Syudy. International Journal of Instruction, 10 (1), 273-288.

[20] Harlen, w., Elsgeest, j. (1992). UNESCO Sourcebook for Science in the Primary School. France. Imprimerie de la Manutention

[21] Joyce, B, Weil, m. \& Calhoun, e. 2009. Models of Teaching ( $8^{\text {th }}$ ed). Models of teaching (translation Achmad Fawai \& Atelia Mirza). Yogyakarta: Pustaka Pelajar

[22] Kan Lin Ting \& Siew Moi Nyet. 2014. the Effect of Outdoor School Ground Lesson on student's Science Process Skills and Scientific Curiosity. Journal of Education and Learning, 3 (4), 96-107. 